\title{
THE INFLUENCE OF MOTHER TONGUE IN SECOND LANGUAGE LEARNING IN PRIMARY SCHOOL
}

\author{
Pule Phindane \\ Language and Social Sciences Education, Faculty of Humanities, \\ Central University of Technology, Free State Bloemfontein 9300 (South Africa)
}

\begin{abstract}
The role of mother tongue in second language learning has been the topic of much recent debates and controversies. This study explores the use of first language (L1) in learning teaching of English as second language (L2) in primary school. The main aim of this article is to establish to what extent and in which instances first language (L1) is used and response of second language educators when they hear first language (L1) in their classroom. Most educators feel that the use of First Language (L1) should be minimised and they feel guilty if they use it a lot. When challenged they find it difficult to say why. Against the use of First Language (L1), it is the general assumption that English should be learned through English, just as you learn your mother tongue using your mother tongue. On the other side, the idea that the learner should learn English like a native speaker does, or tries to 'think in English', is an inappropriate and unachievable thought. The data obtained showed that Second Language (L2) teachers used L1 mainly to provide feedback; teach new vocabulary; explain grammar; build rapport; manage the class; give individual help to learners and save time in lengthy task explanations.
\end{abstract}

Keywords: Acquisition, second language, first language, linguistic.

\section{Introduction}

There have always been opposing opinions about the mother tongue use in second language (L2) classes. Two sides of the story are always narrated when coming to the teaching and learning of second language using mother tongue or first language (L1). There is a claim by some educators that first language (L1) is a valuable influence in the process of teaching and learning of English as the second language, and on the other hand, others avers that first language (L1) should be barred from the process of learning and teaching. This issue can be by no means be abandoned, since the language used in the class substantially influences the acquisition of the target language.

\subsection{The impact of first language use in English learning classroom}

Certain scholars like Atkinson (1987), Harbord (1992), or Scrivener (2005) believe that first language (L1) if it is used accordingly, it can bear positive fruits on the English language teaching and learning process. On the other hand, scholars in the field such as Phillipson (1992), Seligson (1997) or Bonangeune (2009) embrace a different view, and to a certain extent criticize the use of L1. It appears that the use of the L1 is a debatable topic, and the exact role and appropriate extent of the use of L1 has not been clearly defined. It is therefore looks reasonable to assume that a balanced approach which carefully uses L1 to facilitate and enhance the learning absorption of L2 might be the solution to the issue along with adjusting that balance to meet the needs and levels of individual learners.

\subsection{The positive arguments for using $L 1$ in a $L 2$ classroom}

Authors like Deller and Rinvolucri (2002), Briggs (2001); Galali and Cinkara (2017) believe that L1 play an important role in second language learning in a classroom. According to Seftiawan (2018), mother tongue can help six-year-old learners to study second language and master vocabularies through translation. Hanáková and Metruk (2017) observed that L1 can also be used to explain a certain vocabulary, grammar, instructions, organisation purposes and to monitor learners' comprehension. This view is also shared by Alshehri (2017) who observed that L1 in a second language classroom develops good rapport with students. 


\subsection{The negative arguments against using $L 1$ in a $L 2$ classroom}

Regardless of many advantages of using L1 in the L2 classroom there are also some disadvantages of using or overusing L1 in the classroom that may happen. According to Auerbach (1993:5) 'the more the learners are exposed to English, the more quickly they will learn', and for them to be able to learn it, they should be 'forced to use it'. Cook (2001) identifies two reasons for those who support only L2 use in L2 classes. Firstly, the L2 learning process is like the process of L1 learning. Secondly, Cook (2001) states that the acquisition processes of $\mathrm{L} 1$ and $\mathrm{L} 2$ are completely separate.

Zha and Macaro (2014) state that the call for L1 avoidance in L2 classrooms can be based on Krashen's input hypothesis and Long's interaction hypothesis. Krashen (1992) avers that the exposure to comprehensible input increases the learner's opportunity to acquire the language. He adds that comprehensible input should be accompanied by facilitative affective factors like high motivation and self-confidence, language acquisition to take place. Long's interaction hypothesis maintains that the negotiation of meaning in L2 enhances L2 acquisition (Lightbrown and Spada, 2006). Kim and Elder (2008:167) maintain that because the success of the lesson depends on the manner in which the educator uses L2. Learners must be given 'optimal chances' for using L2 in a meaningful way.

\subsection{Arguments on striking the balance in the use of $L 1$ in $L 2$ classroom}

There are many arguments for and against the use of L1 in the process of teaching English or any other language as a second language. Some scholars like Nation (2003) and Harmer (2007) proposes a balanced approach which maximizes the use of L2 but at the same time does recognize the importance of L1 in the classroom. Harmer (2007: 178 -179) also provides ideas on how to reduce the amount of L1 by observing the class during activities and, in his own words, 'even pleading with learners to use English - and offering assistance if necessary' as well as making it clear in the classroom that only English is to be used. Harmer (2001: 132) also indicated that four factors need to be taken into consideration: learners' level of development, previous experience, the stage of the subject, and stage of the lesson. Harbord (1992: 354) maintains that despite L1 being needed to a certain level such as checking comprehension, presenting new structures should be, in his view, done in L2. He believed that educators should be able to communicate meaning of structure without using mother tongue as an option.

Willis (1991:1-2) proposes various ways for convenient L2 use. These techniques include the use of gestures, tone of voice, and demonstration to assist learners understand instruction better, which is, besides a way of reducing the amount of L1 interference, also a source of real-life L2 exposure. According to Hanáková and Metruk (2017) there are no "instant recipes", as every learner and every educator is different, and each classroom conditions and settings are unique. To sum this discussion, it is always up to the educator to know their class and the context in which the English language is to be learned. In view of the opinions of many scholars in the field, it can be said that a balance approach is inevitable when it comes to using L1 in the classroom.

\section{Research methodology}

\subsection{Research background}

The aim of this research is to establish to what extent L1 is used in the English language classrooms at primary school level. Furthermore, the instances in which L1 is used, and the educators' reactions are explored too.

Three research questions were formulated:

What are the most frequent instances in which L1 is used during English language classes?

What is the average time spent on using L1 during English language lessons?

How do the educators react to the use of L1?

\subsection{Research sample}

A total of 15 regular English lessons were observed at "Makgulo Primary school, Motheo district, in South Africa. The observation was performed at a primary school which involved learners from $09-11$ years of age and two educators who are labelled as "X" and "Y". Both the educators and learners were formed by males and females.

\subsection{Instruments and procedure}

A total of 15 English classes were observed with the focus on the time and instances in which L1 was used. Moreover, the educator's reactions to the learners' L1 use were scrutinized. Finally, an informal discussion with the educators after the lessons was held. 


\section{Research results}

\subsection{Observation}

Tables 1 contain the results obtained from observation

Table 1. Observation Primary School.

\begin{tabular}{|c|c|c|c|c|}
\hline Class & Educator & Number of L1 occurrences & Time & Total time \\
\hline 1 & $\mathbf{X}$ & $\begin{array}{l}\text { L: } 4 \text { times } \\
\text { L: } 3 \text { times }\end{array}$ & $\begin{array}{l}\text { L: Several seconds } \\
\text { L: Several seconds }\end{array}$ & Several seconds \\
\hline 2 & $\mathbf{X}$ & $\begin{array}{l}\text { E: } 2 \text { times } \\
\text { L: } 1 \text { time }\end{array}$ & $\begin{array}{l}\text { E: Several seconds } \\
\text { L: Several seconds }\end{array}$ & Several seconds \\
\hline 3 & $\mathbf{X}$ & $\begin{array}{l}\text { L: } 1 \text { time } \\
\text { L: } 1 \text { time }\end{array}$ & $\begin{array}{l}\text { L: Several seconds } \\
\text { L: Several seconds }\end{array}$ & Several seconds \\
\hline 4 & $\mathbf{X}$ & $\begin{array}{l}\text { E: } 1 \text { time } \\
\text { L: } 1 \text { time }\end{array}$ & $\begin{array}{l}\text { E: Several seconds } \\
\text { L: Several seconds }\end{array}$ & Several seconds \\
\hline 5 & $\mathbf{Y}$ & $\begin{array}{l}\text { E: } 9 \text { times } \\
\text { L: } 1 \text { time }\end{array}$ & $\begin{array}{l}\mathrm{E}: 16 \min \\
\mathrm{L}: 2 \mathrm{~min}\end{array}$ & $18 \mathrm{~min}$ \\
\hline 6 & $\mathbf{X}$ & $\begin{array}{l}\text { E: } 1 \text { time } \\
\text { L: } 2 \text { times }\end{array}$ & $\begin{array}{l}\mathrm{E}: 1 \min \\
\mathrm{L}: 1 \mathrm{~min}\end{array}$ & $2 \min$ \\
\hline 7 & $\mathbf{X}$ & $\begin{array}{l}\text { L: } 2 \text { times } \\
\text { L: } 3 \text { times }\end{array}$ & $\begin{array}{l}\text { L: Several seconds } \\
\text { L: } 1 \text { min }\end{array}$ & Several seconds \\
\hline 8 & $\mathbf{Y}$ & $\begin{array}{l}\text { E: } 4 \text { times } \\
\text { L: } 1 \text { time }\end{array}$ & $\begin{array}{l}\text { E: } 11 \min \\
\mathrm{L}: 1 \mathrm{~min}\end{array}$ & $12 \mathrm{~min}$ \\
\hline 9 & $\mathbf{Y}$ & $\begin{array}{l}\text { E: } 4 \text { times } \\
\text { L: } 1 \text { time }\end{array}$ & $\begin{array}{l}\mathrm{E}: 1 \min \\
\mathrm{L}: 1 \mathrm{~min}\end{array}$ & $2 \min$ \\
\hline 10 & $\mathbf{Y}$ & $\begin{array}{l}\text { E: } 8 \text { times } \\
\text { L: } 2 \text { times }\end{array}$ & $\begin{array}{l}\text { E: } 10 \min \\
L: 2 \min \end{array}$ & $12 \mathrm{~min}$ \\
\hline 11 & $\mathbf{Y}$ & $\begin{array}{l}\text { E: } 5 \text { times } \\
\text { L: } 2 \text { times }\end{array}$ & $\begin{array}{l}\mathrm{E}: 4 \mathrm{~min} \\
\mathrm{~L}: 3 \mathrm{~min}\end{array}$ & $7 \min$ \\
\hline 12 & $\mathbf{X}$ & $\begin{array}{l}\text { E: } 5 \text { times } \\
\text { L: } 2 \text { times }\end{array}$ & $\begin{array}{l}\text { E: } 7 \text { min } \\
\text { L: } 2 \text { min }\end{array}$ & $9 \min$ \\
\hline 13 & $\mathbf{Y}$ & L: 1 time & L: Several seconds & Several seconds \\
\hline 14 & $\mathbf{Y}$ & $\begin{array}{l}\text { L: } 2 \text { times } \\
\text { E: } 5 \text { times }\end{array}$ & $\begin{array}{l}\mathrm{L}: 1 \mathrm{~min} \\
\mathrm{E}: 9 \mathrm{~min}\end{array}$ & $10 \mathrm{~min}$ \\
\hline 15 & $\mathbf{X}$ & E: 1 time & E: Several seconds & Several seconds \\
\hline
\end{tabular}

The observation table above display the following results: The overall average time spent on using L1 in all 15 classes was 8.4 min per one lesson, which accounts for $19 \%$ of the lesson. The duration of one lesson was $45 \mathrm{~min}$. The average time of learners' use of L1 was $1.7 \mathrm{~min}$ per one lesson, which comprises $4 \%$ of the lesson. The average time of educators' use of L1 was 6.7 min per one lesson, which makes up $15 \%$ of the lesson. The observation results show that each observed lesson involved at least some usage of L1. In other words, a lesson in which L1 would not be used at all did not occur during the observation. The average time spent on using L1 (educators + learners) during the observation of 15 classes was 4.8 min per one lesson, which accounts for $11 \%$ of the lesson. The average time of educators' use of L1 during one lesson was 4 min per one lesson, which makes up $9 \%$ of the lesson. As already mentioned, the two educators who were observed were labelled as " $\mathbf{X}$ " and "Y". Individual evaluations of each teacher reveal that there are significant differences between the educators in terms of using L1. In the classes of educator "X", L1 was used only for a several seconds, and the observation results demonstrate that the learners of this educator are used to using L2, and only use L1 when needed. In the classes of educator "Y", however, L1 was used frequently; the average time was 4.7 min per one lesson, which makes up more than $10 \%$ of the lesson. In the classes of educator "Y", L1 was used similarly often, around 4.7 min per one lesson, which accounts for $10 \%$ of the lesson. It is obvious that in some cases, L1 was barely used, and, in other lessons, L1 was spoken for 12 or $18 \mathrm{~min}$. This clearly reveals that although these were the classes spent on new grammar, the particular educators did not provide their learners with enough space for the use of L2. It can be perhaps concluded that the lessons did not contain a communicative component.

Another feature which was the focus of attention during the observation was the amount of L1 occurrences. The results show that during the observation of 15 classes, the learners used L1 32 times, and 
the educators used L1 45 times. The most frequent instances in which L1 was used were specific vocabulary - in this case, the learners were usually asking for a meaning or a translation of an unknown word, explaining grammar, giving instructions, organisation purposes, and checking understanding. While in some cases, e.g. when an unknown word appeared, the learners asked the educator for a translation which usually led to an explanation in L1 that lasted for several seconds. However, the educators occasionally spent a minute or two explaining the meaning of a word or an expression in L1. When explaining a new grammar component, the educators usually used L1, sometimes to point out the differences, but occasionally, a long explanation of grammar in L1 happened. In a few cases, the educators provided materials, for example a test, in which learners were supposed to translate language items from L1 into L2. The educators' response was, in the majority of occurrences, the continuation in L2 so the learners' L1 was not paid attention. The educators were sometimes "pretending" they did not hear the learners' L1 use, which was probably an attempt to make the learner realize they did something undesired. Another very common response to the use of L1 was requesting the use of L2 instead of L1 from the learners, after which the learner remained quiet or explained in L1 that he or she is not able to provide a sentence or a question in L2. It should be noted that in some cases, the atmosphere in class became rather stressful, especially when the learners were using too much L1 and their educator asked them to use L2. It was, therefore, startling when the same educator used L1 during that lesson without any apparent reason. It is important to point out that sometimes, when the learners were asked for a specific word translation or explanation of a grammatical feature, the educators did not always provide them with an answer only in L1 or L2, but very often a mixture of L1 and L2 was used. Even though the educators required their learners to use L2, the educators themselves sometimes used the mixture of L1 and L2. This seemed rather baffling for the learners, and it might be the result of absenting rules for the L1 use in the class. Finally, it is worth mentioning that although in the majority of classes, the use of L1 did not exceed $15 \mathrm{~min}$, there were four classes in which the use of L1 exceeded $15 \mathrm{~min}$. This accounts for one third of the lesson duration. The average time of L1 use, which was 8.4 min, appears to be affected by the fact that while in some lessons, the use of L1 did not exceed a minute amount of time (several seconds), in other lessons, L1 was used for more than $15 \mathrm{~min}$.

\section{Discussion}

The research results demonstrate that L1 is always present in the L2 lessons. The average time spent on using L1 accounts for $19 \%$ of the lesson.

As far as the instances in which L1 is most commonly used, it was observed that the most frequent cases in which L1 was used were specific vocabulary, explaining grammar, instructions, organisation purposes, and checking understanding. During the discussions with the educators, which took place after the lessons in the form of an informal dialogue, the study reveals that there are various reasons for using L1 such as saving time, avoiding misunderstandings, and attempting to point out the differences between certain elements such as grammar issues in L1 and L2. In the majority of cases, the teachers' response to the learners' use of L1 was continuation in L2, and hence the learners' L1 was usually not recognized. Instead, the educators "pretended" not to notice the learners' L1 use as well and they requested the learners to say or ask the same thing in L2. It should be emphasized that during the observation, it was sometimes rather obvious that the teachers had not established rules for the usage of L1 in their lessons. This fact often seemed to generate uncertainty because sometimes the learners' use of L1, especially in unnecessary instances when L1 was not needed such as for the clarification of understanding etc., was ignored by the educators, while in other cases, the educators urged the learners to use L2. This seems to be rather misleading for learners in general, and L2 educators should always set clear rules about the use of L1 in classes at the beginning of a school year.

\section{Conclusion}

This paper focused on the use of the mother tongue in the process of teaching and learning English at Primary school in South Africa. The language used in the classroom cannot be disregarded since it directly and greatly influences the acquisition of $\mathrm{L} 2$. The central aim of this study was to determine to what extent L1 is used in the English language classrooms, in which instances it is used, and what the educator's responses to the use of L1 are. Firstly, it was observed that the average time spent on using L1 during English language classes is 8.4 min per one lesson, which accounts for $19 \%$ of the lesson. Secondly, the most frequent instances in which L1 is used during English language classes were specific vocabulary, explaining grammar, instructions, organisation purposes, and checking understanding. Finally, it was observed that the teachers' reactions are, in the majority of cases, continuation in L2, "pretending" not to hear the student's L1 use and requesting the use of L2 instead of L1 from the learners. The research results 
indicate that L1 is always present in the classes. This is an interesting finding since using adequate amount of L2 in EFL classes could be regarded as a main goal in L2 classes. To summarize, the language used in the classroom plays a major role in the process of L2 teaching as it directly influences the acquisition of L2. Therefore, the teachers ought to always set clear rules about the use of L1 in their classes.

\section{References}

Alshehri, E. (2017). Using learners' first language in EFL classrooms. IAFOR Journal of Language Learning, 3(1), $20-33$.

Atkinson, D. (1987). The Mother Tongue in the Classroom: A neglected Resource? ELT Journal, 41(4) 241-247.

Auerbach, E. (1993). Re-examining English only in the ESL Classroom. TESOL Quarterly, 27(1), 9-32.

Bouangeune, S. (2009). Using L1 in Teaching Vocabulary to low English Proficiency Level Students: A Case Study at the University of Laos. English Language Teaching Journal, 2 (3),186-193.

Briggs, M. (2001). Teacher and Student Attitudes to English-only \& L1 in the EFL Classroom. Bristol: University of Bristol.

Cook, V. (2001). Using the First Language in the Classroom. The Canadian Modern Language Review/La Revue Canadienne des Languages Vivantes, 57(3), 402-423.

Deller, S. \& Rinvolucri, M. (2002). Using the Mother Tongue: Making the Most of Learners' language. London: Delta Publishing.

Galali, A., \& Cinkara, E. (2017). The Use of L1 in English as a foreign language classes: Insights from Iraqi tertiary level students. Advances in Language and Literary Studies, 8 (5), $54-64$. Retrieved from

Hanakova, M., \& Metruk, R. (2017). The use of L1 in the process of teaching English. Modern Journal of Language Teaching Methods, 7 (8), $380-389$.

Harbord, J. (1992). The Use of the Mother Tongue in the Classroom. ELT Journal, 46(4), 350-355.

Harmer, J. (2001). The Practice of English Language Teaching. Harlow: Pearson Education Limited.

Harmer, J. (2007). How to Teach English. Harlow: Longman.

Kim, S. H. O., \& Elder, C. (2008). Target language use in foreign language classrooms: Practices and perceptions of two native speaker teachers in New Zealand. Language, Culture and Curriculum, 21(2), 167-185.

Nation, P. (2003). The Role of the First Language in Foreign Language Learning. Asian EFL Journal, 5(2). Retrieved from asianefljournal.com/june_2003_PN.phpz.

Phillipson, R. (1992). Linguistic Imperialism. Oxford: Oxford University Press.

Scrivener. J. (2005). Learning Teaching. (2nd ed.). Oxford: MacMillan Education.

Seligson, P. (1997). Helping Students to Speak. Spain: Richmond Publishing.

Willis, J. (1991). Teaching English through English. Harlow: Longman. 